\section{TEXTO \& CONTEXTO
ZENGERMAGEN}

TEXT \& CONTEXT NURSING TEXTO \& CONTEXTO ENFERMERÍA

\title{
EFFECTIVENESS OF AURICULAR THERAPY ON LABOR PAIN: A RANDOMIZED CLINICAL TRIAL
}

\section{Reginaldo Roque Mafetoni' Mariana Haddad Rodrigues ${ }^{2}$ Flora Maria Barbosa da Silva ${ }^{3}$ Lia Maristela da Silva Jacob ${ }^{4}$ Antonieta Keiko Kakuda Shimo ${ }^{4}$}

\begin{abstract}
${ }^{1}$ Universidade Estadual de Campinas, Centro de Atenção Integral à Saúde da Mulher. Campinas, São Paulo, Brasil. ${ }^{2}$ Hospital São Francisco. Cambé, Paraná, Brasil. ${ }^{3}$ National Health Service England. London, United Kigdon. ${ }^{4}$ Universidade Estadual de Campinas, Faculdade de Enfermagem. Campinas, São Paulo, Brasil.
\end{abstract}

\begin{abstract}
Objective: to evaluate the effectiveness of auricular therapy on pain in the active phase of labor.

Method: a randomized, parallel and triple-blind clinical trial, conducted from April 2015 to June 2016. A total of 102 pregnant women with a gestational age $\geq 37$ weeks, cervical dilatation $\geq 4 \mathrm{~cm}$ and two or more contractions within 10 minutes, randomly divided into three groups: intervention (auricular therapy), placebo (sham points) and control (without intervention). Auricular therapy was applied with crystal microspheres in four strategic points and pain intensity evaluated by a Visual and Analog Scale. For the analyses, the following tests were used: Kruskal-Wallis and Generalized estimating equations.

Results: pain intensity averages were similar at admission (intervention: $7.2 \pm 1.6$ vs placebo: $6.9 \pm 2.4$ vs control: 7.5 \pm 1.8 ; $p$-value $=0.4475$ ), but with 60 minutes (intervention: $6.8 \pm 1.9$ vs placebo: $7.5 \pm 2.4$ vs control: $8.3 \pm 1.8$; $p=0.0060$ ) and 120 minutes (intervention: $7.1 \pm 1.9$ vs placebo: $8.0 \pm 2.4$ vs control: $8.8 \pm 1.9$; $p$-value $=0.039$ ), there was a significant increase in pain scores between parturients of the placebo and control groups.

Conclusion: parturients who received auricular therapy during labor showed a reduction in pain intensity, which may characterize the effectiveness of the therapy in this phase. Registration: No. RBR-47hhbj.
\end{abstract}

DESCRIPTORES: Complementary therapies. Auricular therapy. Labor. Labor pain. Obstetric nursing. 


\section{EFETIVIDADE DA AURICULOTERAPIA SOBRE A DOR NO TRABALHO DE PARTO: ENSAIO CLÍNICO RANDOMIZADO}

\section{RESUMO}

Objetivo: avaliar a efetividade da auriculoterapia sobre a dor na fase ativa do trabalho de parto.

Método: ensaio clínico randomizado, paralelo e triplo-cego, realizado de abril de 2015 a junho de 2016. Participaram 102 parturientes de idade gestacional $\geq 37$ semanas, dilatação cervical $\geq 4 \mathrm{~cm}$ e duas ou mais contrações em $10 \mathrm{~min}$, divididas aleatoriamente em três grupos: intervenção (auriculoterapia), placebo (pontos sham) e controle (sem intervenção). A auriculoterapia foi aplicada com microesferas de cristais em quatro pontos estratégicos e a intensidade da dor avaliada por uma Escala Visual e Analógica. Para as análises, foram utilizados os testes: Kruskal-Wallis e Generalized estimating equations.

Resultados: as médias de intensidade da dor foram parecidas na admissão (intervenção:7,2 $\pm 1,6 \mathrm{vs}$ placebo:6,9 $\pm 2,4$ vs controle:7,5 $\pm 1,8 ; p$-valor $=0,4475$ ), porém com 60 minutos (intervenção: $6,8 \pm 1,9$ vs placebo:7,5 $\pm 2,4$ vs controle:8,3 $\pm 1,8 ; p=0,0060$ ) e 120 minutos (intervenção:7, $1 \pm 1,9$ vs placebo:8,0 $\pm 2,4$ vs controle: $8,8 \pm 1,9$; $p$-valor $=0,039$ ), houve aumento significativo nos escores dor entre as parturientes dos grupos placebo e controle.

Conclusão: as parturientes que receberam auriculoterapia durante o trabalho de parto mostraram redução na intensidade da dor, que pode caracterizar a efetividade da terapia nessa fase.

DESCRITORES: Terapias complementares. Auriculoterapia. Trabalho de parto. Dor do parto. Enfermagem obstétrica.

\section{EFECTIVIDAD DE LA AURÍCULOTERAPIA PARA EL DOLOR DURANTE EL TRABAJO DE PARTO: UN ENSAYO CLÍNICO ALEATORIZADO}

\section{RESUMEN}

Objetivo: evaluar la efectividad de la auriculoterapia sobre el dolor en la fase activa del trabajo de parto. Método: un ensayo clínico aleatorizado, paralelo y triple ciego, realizado entre abril de 2015 y junio de 2016. Participaron 102 parturientas con una edad gestacional de al menos 37 semanas, dilatación cervical mínima de $4 \mathrm{~cm}$ y dos o más contracciones en 10 minutos, divididas aleatoriamente en tres grupos: intervención (auriculoterapia), placebo (puntos sham) y control (sin intervención). La auriculoterapia se aplicó con microesferas de cristales en cuatro puntos estratégicos y la intensidad del dolor se evaluó por medio de una Escala Visual y Analógica. Para los análisis se utilizaron las siguientes pruebas: Kruskal-Wallis y Ecuaciones de estimaciones generalizadas (Generalized Estimating Equations, GEE).

Resultados: los valores medios de la intensidad del dolor fueron parecidos al momento de la admisión (intervención:7,2 $\pm 1,6$ vs placebo:6,9 $\pm 2,4$ vs control:7,5 $\pm 1,8$; valor-p $=0,4475$ ), pero a los 60 minutos (intervención: $6,8 \pm 1,9$ vs placebo: $7,5 \pm 2,4$ vs control:8,3 $\pm 1,8 ; p=0,0060$ ) yalos 120 minutos (intervención:7,1 $\pm 1,9$ vs placebo: $8,0 \pm 2,4$ vs control: $8,8 \pm 1,9$; valor- $p=0,039$ ) se registró un aumento significativo en los puntajes de dolor entre las parturientas de los grupos placebo y de control.

Conclusión: en las parturientas que recibieron auriculoterapia durante el trabajo de parto se evidenció una reducción del dolor, que puede caracterizar la efectividad de la terapia en esta fase.

DESCRIPTORES: Terapias complementarias. Auriculoterapia. Trabajo de parto. Dolor en el parto. Enfermería obstétrica. 


\section{INTRODUCTION}

During labor, the pain of contractions, when uncontrolled, can cause several changes in maternal physiology and personal satisfaction with childbirth. Pain promotes increased catecholamine and cortisol secretion, resulting in physiological responses such as increased cardiac output, blood pressure, and peripheral vascular resistance. ${ }^{1}$ Therefore, the relief of this should be a conduct to be performed, especially when it has an incidence on a maternal organism with associated complication or fetal-placental unit with low oxygen reserve.

The parturient perception of pain depends on the intensity and duration of uterine contractions, on the physical condition and on a series of factors, namely: psychological, cultural, educational, as well as on each woman's previous experience, expectations and individuality. Predictive factors for increased pain perception during labor include the following: nulliparity, absence of companion, use of maneuvers to accelerate labor, such as amniotomy and intravenous oxytocin, unable to move, history of dysmenorrhea, and fetal pressure on pelvic structures during the expulsive period. ${ }^{2-3}$

Acupuncture and acupressure are two therapies from the Traditional Chinese Medicine (TCM) aimed at reducing the pain and the symptoms of various diseases. In the obstetric specialty, they are studied and currently used, reducing labor pain, cervical ripening, labor induction, among other intra-partum indications. ${ }^{4-5}$ Acupuncture has been described as effective for induction, premature rupture of the membranes and cervical ripening. ${ }^{4}$ With regard to acupressure, significant results were identified in pain reduction and duration of labor. Although acupuncture and acupressure have enough published studies, Randomized Clinical Trials (RCTs) with greater metholodigical rigor are needed to evaluate the effectiveness of these therapies on pain and labor evolution. ${ }^{4,6}$

Auricular therapy or auricular acupuncture is a modality of TCM, performed by stimulating reflex points in the auricular region, but little studied in the pain of parturition. A review with metaanalysis ${ }^{7}$ showed that auricular therapy decreased pain intensity, especially for chronic low back pain and chronic tension headaches. Another study ${ }^{8}$ showed the beneficial results of this therapy in reducing stress and anxiety.

Auricular therapy has some points described for the treatment of obstetric dystocia, and for the reduction of the expulsive period and of labor pain ${ }^{9-10}$ and can be an alternative of care and comfort for parturients through non-invasive methods. However, the scarcity of studies on pain and during labor limits the establishment of this therapy in obstetric practice. In this context, the present study aimed to evaluate the effectiveness of auricular therapy on pain in parturients in the active phase of labor.

\section{METHOD}

This is a randomized and parallel clinical trial conducted from April 2015 to June 2016, with preliminary data previously published. ${ }^{11}$

The research participants were parturients, admitted for childbirth care to a public teaching hospital, located in a city in the state of São Paulo, Brazil. Practices considered humanizing care have been used in the local obstetric unit of the study, such as the right of companion of choice of women during labor and delivery and joint accommodation. The parturients can also use the shower in the bathroom, the lumbosacral massage, the breathing exercise, the Swiss ball, and request pharmacological analgesia. However, intravenous oxytocin, prostaglandins, fasting and amniotomy are routinely used in labor and delivery.

Parturients were included of any age or parity from 37 weeks of gestation on spontaneous, induced and/or conducted labor with dilation $\geq 4 \mathrm{~cm}$, two or more painful contractions within 10 minutes, with intact skin in the ear and whose fetus was alive, in cephalic presentation of vertex and with good 
conditions of vitality. We excluded cases of women with dilatation $\geq 7 \mathrm{~cm}$, severe preeclampsia, anterior cesarean section, immediate indication of this surgical procedure and use of analgesic medication less than 6 hours after admission to the study.

The inclusion of parturients in the study groups was done through hidden allocation, using sequentially sealed and numbered opaque envelopes opened by the main researcher after inclusion of the parturient in the study. The envelopes were opened in the presence of two employees of the unit, not participants of the study and who did not assist the women. Study participants were randomly allocated to three groups: Intervention Group (IG) with $1.5 \mathrm{~mm}$ microspheres of polished crystal; Placebo Group (PG), with glass microspheres, like those of crystals but whihc, when not manipulated, do not activate the auricular points; and Control Group (CG), without intervention.

The study used the triple-blind method. However, to perform the intervention, the main researcher knew about the allocation of the parturients, but the evaluators who collected the data for the studied variables and the study outcomes, and the professionals who provided assistance and could change conduct during labor (prescription of analgesics and analgesia), did not know to which group each participant belonged to. Data was transcribed by the evaluators in instruments identified by numerical sequence and the groups by distinct letters, and then sent to a statistical professional for analysis who also did not identify the allocation group. In the third comparison (CG), due to the lack of fixation of the adhesive microspheres in the auricular pavilion, the allocation of the parturient was noticeable, thus a particularity of this RCT; except for the statistics professional who remained blinded in the three study groups.

To collect sociodemographic and clinical data, an instrument was submitted to content validity analysis, conducted by five judges with experience in the area of midwifery and/or TCM.

The evaluation team was made up of five nursing technicians from the obstetric unit, who were trained to collect research data and to use the Visual and Analog Scale (VAS). The main researcher responsible for the application of auricular therapy underwent training of the technique in two courses, lasting 64 hours.

The parturients were approached in the Pre-delivery (PD) or Pre-delivery, Childbirth and Postpartum (PCP) rooms, evaluated for eligibility, and invited to participate in the study. After agreeing to participate, they signed the Free and Informed Consent Form, and were allocated by lot order and accompanied by the evaluating team until the day after delivery. There was no difference in the treatment offered to women in the three study groups.

For the IG, the following points were used according to the Chinese auicular map: i) shenmen, which predisposes the brainstem and cortex to receive, condition and encode the auricular reflexes, having sedative and analgesic effects; ii) uterus, indicated for gynecological and obstetric changes, induction of labor or reduction of the expulsive period and reduction of postpartum pain; iii) the area of neurasthenia, indicated for the treatment of anxiety; iv) endocrine, which regulates the functions of endogenous secretion glands, being used in gynecological disorders, among others. ${ }^{9-10}$

For the application of the crystal microspheres, antisepsis was performed prior to the procedure with $70^{\circ}$ ethyl alcohol in the auricle; the points were surveyed with pressure exerted by the point probe and defined close to the topography indicated on the "point map" at the most painful place on palpation. As the point was located, the crystal was fixed with adhesive to the IG parturients' ear and pressed individually for a minute or until it caused bearable pain to induce stimulation. In the PG, the point probe was used to indicate the location and to affix the glass microspheres in the sham points (not indicated for the proposed treatment): ankle, knee, tooth and jaw, without pressure stimuli at any time of the study. The parturients allocated in the CG were followed for the same period and evaluated by the VAS, as in the other groups. 
To assess the primary outcomes of this RCT - the pain intensity reported in labor - pre-elaborated questions were used: “... in relation to pain, is it the same?"; “... got worse?”; “... improved?”, and through a VAS, developed by the pain control team in the Anesthesiology subject from Hospital das Clínicas of the School of Medicine of São Paulo. ${ }^{12}$ The scale is numbered from ten to zero, ten being the equivalent of torturous pain and zero being absence of pain. The pre-elaborated questions and the VAS were applied upon admission of women to the study and then reapplied at 30,60 and 120 minutes by the evaluating team.

Secondary outcomes of this RCT were due to the use of analgesics and analgesia during labor between study groups. In turn, the control variables were described by the general characteristics (Table 1 - in the results section), by the DeLee plan, which measures the height of the fetus presentation in relation to the sciatic spines of the middle basin strait ${ }^{13}$ and the other obstetric characteristics (Table 2 -described in the results section).

The sample size calculation was performed in order to compare the groups regarding the variables of pain intensity and duration of labor in an ANOVA model, since these variables are quantitative and three groups are compared; the estimates of the mean variables for each of the groups and the mean square standard deviation (sd) of the model error were based on two previous studies ${ }^{14-15}$ on the effects of acupressure on pain and duration of labor; a 2.11 point difference in the VAS pain score (graded from zero to 10) with 60 minutes of treatment and a 407.04 minute difference in labor time. In addition, a significance level of $5 \%$ and a test power of $80 \%$ in the sample calculations were assumed. The calculation resulted in a sample of 17 individuals per group for the pain intensity variable; and a sample of 33 individuals per group, for the variable duration of labor. A sample of 33 individuals per group was considered because the study was part of a larger project that includes other parameters of interest, and one individual per group was added to the sample calculation, predicting losses, for final a total sample of 102 individuals.

Comparisons between groups regarding quantitative variables were performed using the Kruskal-Wallis test. Comparisons between groups and evaluation periods were performed using Generalized Estimating Equations (GEE). Estimates obtained of mean difference, confidence intervals, and p-values were presented; this modeling was applied to compare the groups in relation to the VAS pain intensity variable, and also the obtained estimates of relative risk, as well as the respective confidence intervals and p-values. For associations between the groups and the categorical variables, the chi-square or Fisher's exact association test was used. In the comparison tests for the variables evaluated over time, the Bonferroni correction was applied at the significance level. In the case of the VAS variable, $p$-values below 0.0071 were considered significant. For the other analyses, a significance level of $5 \%$ was considered and the software Statistical Analysis System (SAS), version 9.4, was used.

The women who agreed to participate in the study signed an informed consent form.

\section{RESULTS}

A total of 102 parturients participated in this study, randomly assigned to three groups. There were no losses after randomization, only the following were excluded from the analyses: VAS and pain perception of parturients whose delivery occurred before 120 minutes (Figure 1). 


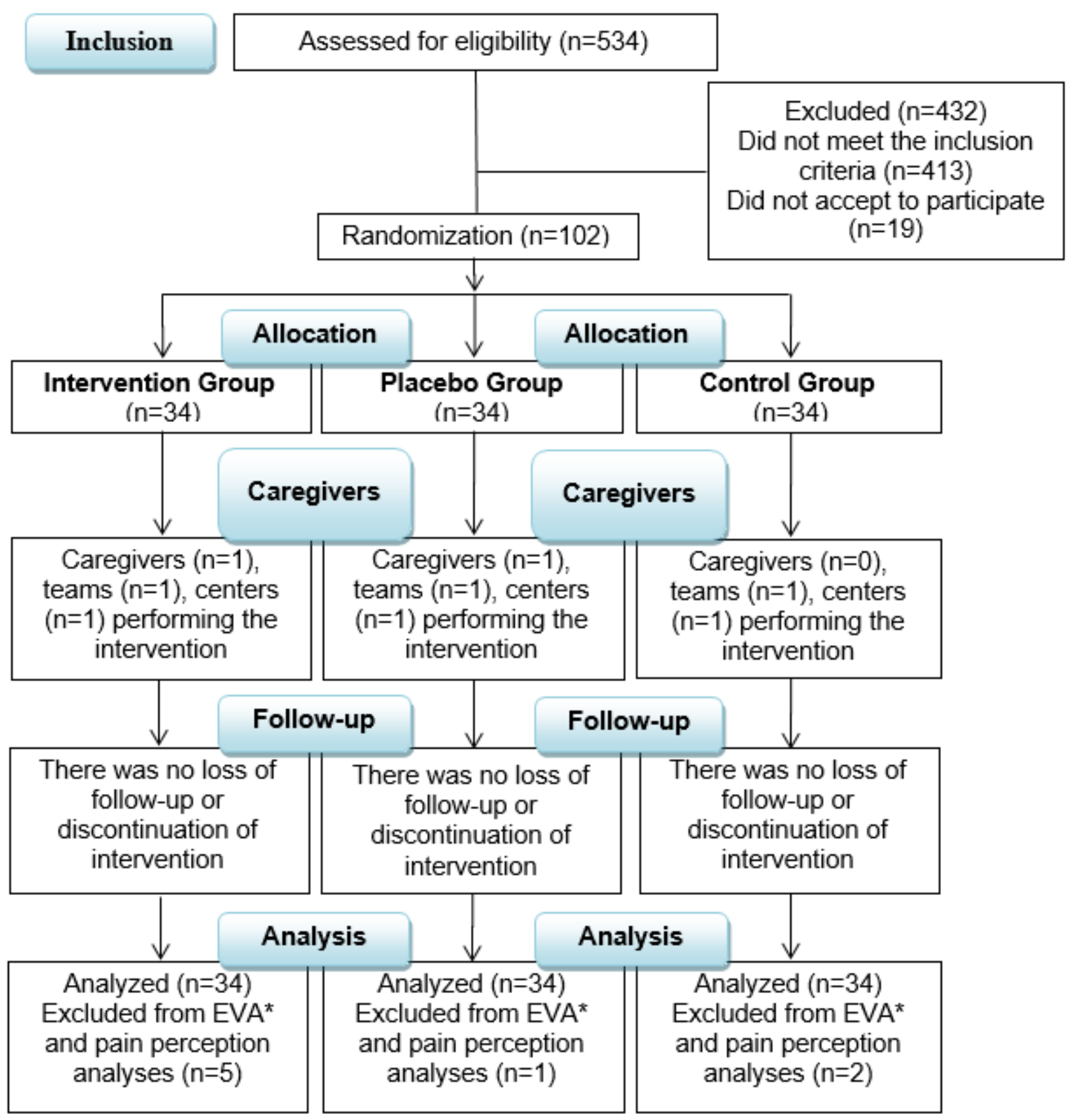

Figure 1 - Flowchart of the study participants. Campinas, São Paulo, 2016.

Source: Adapted from Consort. ${ }^{16}$

*Visual and Analog Scale

Table 1 shows the general characteristics of the parturients according to allocation; the groups were homogeneous, thus, there was no statistically significant difference in the analyses. Most women did not attend preparation and guidance courses on the evolution of labor or on the use of alternative, non-pharmacological methods during delivery care (PG: $88.2 \%$; IG and PG: 85.3\%, p-value=1.000, Fisher's exact test)

De Lee's plan showed no difference between groups, with most parturients at $-3 \mathrm{~cm}$ in height at fetal presentation, except for two in the CG, one in the IG and one in the PG with $-2 \mathrm{~cm}$. The other obstetric characteristics and labor conduction, described in Table 2, showed no differences between the groups. 
Table 1 - Distribution of the parturients, according to general characteristics and study groups. Campinas, São Paulo, 2016

\begin{tabular}{|c|c|c|c|c|}
\hline \multirow{3}{*}{ Characteristics } & \multicolumn{4}{|c|}{ Study groups } \\
\hline & Intervention & Placebo & Control & $p$-value \\
\hline & $(n=34)$ & $(n=34)$ & $(n=34)$ & \\
\hline Age (years old), mean (sd) & $23.9(5.8)$ & $25.1(7.0)$ & $22.7(5.3)$ & $0.3503^{*}$ \\
\hline Schooling (years of schooling), average (sd) & $10.7(3.1)$ & $9.9(2.4)$ & $10.7(3.1)$ & $0.4567^{*}$ \\
\hline \multicolumn{5}{|l|}{ Skin color/Race - self-declared, n (\%) } \\
\hline Caucasian & $13(38.3)$ & $18(52.9)$ & $13(38.3)$ & \multirow{2}{*}{$0.3682^{\dagger}$} \\
\hline Not white & $21(61.7)$ & $16(47.1)$ & $21(61.7)$ & \\
\hline \multicolumn{5}{|l|}{ Marital status, $\mathrm{n}(\%)$} \\
\hline Has a partner & $29(85.3)$ & $33(97.1)$ & $32(94.1)$ & \multirow[t]{2}{*}{$0.2674^{\dagger}$} \\
\hline No partner & $05(14.7)$ & $01(2.9)$ & $02(5.9)$ & \\
\hline Companion of choice during hospitalization, $\mathrm{n}(\%)$ & $33(97.1)$ & $31(91.2)$ & $32(94.1)$ & $0.7613^{\ddagger}$ \\
\hline \multicolumn{5}{|l|}{ Knows about auricular therapy, n (\%) } \\
\hline Does not know about the therapy & $22(64.7)$ & $20(58.8)$ & $19(55.9)$ & \multirow{3}{*}{$0.7375^{\ddagger}$} \\
\hline Had some information, but did not use it & $10(29.4)$ & $11(32.4)$ & $14(41.2)$ & \\
\hline Had information and used it & $02(5.9)$ & $03(8.8)$ & $01(2.9)$ & \\
\hline \multicolumn{5}{|l|}{ Parity, n (\%) } \\
\hline Nulliparous & $27(79.4)$ & $25(73.5)$ & $25(73.5)$ & \multirow[t]{2}{*}{$0.8090^{*}$} \\
\hline Multiparous & $07(20.6)$ & $09(26.5)$ & $09(26.5)$ & \\
\hline Number of prenatal consultations, average (sd) & $9.3(2.2)$ & $9.9(2.4)$ & $8.9(2.5)$ & $0.4492^{*}$ \\
\hline
\end{tabular}

Table 2 - Distribution of the obstetric characteristics of the parturients and conduction of labor by study groups. Campinas, São Paulo, 2016.

\begin{tabular}{|c|c|c|c|c|}
\hline \multirow{3}{*}{ Variables } & \multicolumn{3}{|c|}{ Study groups } & \multirow{3}{*}{ p-value } \\
\hline & Intervention & Placebo & Control & \\
\hline & $(n=34)$ & $(n=34)$ & $(n=34)$ & \\
\hline \multicolumn{5}{|l|}{ Amniotic membranes, $\mathrm{n}(\%)$} \\
\hline Integral & $25(73.5)$ & $21(61.8)$ & $19(55.9)$ & \\
\hline Artificial route & $03(8.8)$ & $06(17.7)$ & $03(8.8)$ & $0.3378^{+}$ \\
\hline Spontaneous route & $06(17.7)$ & $07(20.5)$ & $12(35.3)$ & \\
\hline Spontaneous labor, n (\%) & $25(73.5)$ & $16(47.1)$ & 19 (55.9) & $0.0781^{*}$ \\
\hline Cervical dilatation $(\mathrm{cm})$, average $(\mathrm{sd})$ & $4.6(0.9)$ & $4.8(0.8)$ & $4.5(0.8)$ & $0.3915^{\ddagger}$ \\
\hline No. of contractions, mean (sd) & $3.1(0.9)$ & $3.2(0.7)$ & $3.3(0.9)$ & $0.5986^{\ddagger}$ \\
\hline Duration of contractions (sec), average (sd) & $45.8(7.7)$ & $43.6(8.0)$ & $46.6(8.1)$ & $0.0853^{\ddagger}$ \\
\hline \multicolumn{5}{|l|}{ Intensity of contractions, $\mathrm{n}(\%)$} \\
\hline Poor & $02(5.8)$ & $06(17.6)$ & $00(0.0)$ & \\
\hline Moderate & $16(47.1)$ & $17(50.0)$ & $22(64.7)$ & $0.0634^{\dagger}$ \\
\hline Strong & $16(47.1)$ & $11(32.4)$ & $12(35.3)$ & \\
\hline \multicolumn{5}{|l|}{ Conduction of labor, $\mathrm{n}(\%)$} \\
\hline Prostaglandin & $07(20.6)$ & $10(29.4)$ & $11(32.4)$ & $0.5273^{*}$ \\
\hline Oxytocin & $18(52.9)$ & $16(47.1)$ & $21(61.8)$ & $0.4725^{*}$ \\
\hline $\begin{array}{l}\text { Use of oxytocin solution (SG } 5 \% 500 \mathrm{ml}+ \\
1 \text { ampoule oxytocin } 5 \mathrm{UI})(\mathrm{ml}) \text {, mean (sd) }\end{array}$ & $231.9(312.5)$ & $\begin{array}{c}342.2 \\
(387.3)\end{array}$ & $\begin{array}{c}179.9 \\
(296.7)\end{array}$ & $0.1242^{\ddagger}$ \\
\hline
\end{tabular}

$\mathrm{Sd}=$ standard deviation $\mathrm{p}<0.05$; ${ }^{*}$ Chi-square test; 'Fisher's exact test; ‡Kruskal-Wallis test 
Tables 3 and 4 analyzed data on parturients whose delivery did not occur before 120 minutes, thus concluding the three VAS evaluation periods and answering the pre-elaborated questions (pain perception).

Table 3 - Comparison of pain intensity and perception between study groups. Campinas, São Paulo, 2016

\begin{tabular}{|c|c|c|c|c|c|c|c|}
\hline \multirow{3}{*}{ Variables } & \multicolumn{6}{|c|}{ Study groups } & \multirow{4}{*}{$p$-value } \\
\hline & \multirow{2}{*}{\multicolumn{2}{|c|}{$\begin{array}{c}\text { Intervention } \\
(\mathrm{n}=29)\end{array}$}} & \multirow{2}{*}{\multicolumn{2}{|c|}{$\begin{array}{c}\text { Placebo } \\
(n=33)\end{array}$}} & \multirow{2}{*}{\multicolumn{2}{|c|}{$\begin{array}{c}\text { Control } \\
(n=32)\end{array}$}} & \\
\hline & & & & & & & \\
\hline Before treatment & average & sd $\ddagger$ & average & sd & average & sd & \\
\hline VAS† & 7.2 & 1.6 & 6.9 & 2.4 & 7.5 & 1.8 & $0.4475^{*}$ \\
\hline After $30 \mathrm{~min}$ & average & $s d$ & average & sd & average & sd & \\
\hline VAS & 6.7 & 2.0 & 7.1 & 2.4 & 7.9 & 1.7 & $0.0455^{*}$ \\
\hline Pain perception & $\mathrm{n}$ & $\%$ & $\mathrm{n}$ & $\%$ & $\mathrm{~N}$ & $\%$ & \\
\hline Relieved & 10 & 34.5 & 01 & 3.0 & 00 & 0.00 & \\
\hline Same & 15 & 51.7 & 21 & 63.7 & 19 & 59.4 & \\
\hline Worsened & 04 & 13.8 & 11 & 33.3 & 13 & 40.6 & \\
\hline After $60 \mathrm{~min}$ & average & sd & average & sd & average & sd & \\
\hline VAS & 6.8 & 1.9 & 7.5 & 2.4 & 8.3 & 1.8 & $0.0060^{*}$ \\
\hline Pain perception & $\mathrm{n}$ & $\%$ & $\mathrm{n}$ & $\%$ & $\mathrm{~N}$ & $\%$ & \\
\hline Relieved & 11 & 37.9 & 01 & 3.0 & 01 & 3.0 & \\
\hline Same & 13 & 44.8 & 13 & 39.4 & 13 & 40.6 & \\
\hline Worsened & 05 & 17.3 & 19 & 57.6 & 18 & 56.3 & \\
\hline After $120 \mathrm{~min}$ & average & sd & average & sd & average & sd & \\
\hline VAS & 7.1 & 1.9 & 8.0 & 2.4 & 8.8 & 1.9 & $0.0039^{*}$ \\
\hline Pain perception & $\mathrm{n}$ & $\%$ & $\mathrm{n}$ & $\%$ & $\mathrm{~N}$ & $\%$ & \\
\hline Relieved & 05 & 17.2 & 00 & 0.00 & 00 & 0.0 & \\
\hline Same & 16 & 55.2 & 10 & 30.3 & 09 & 28.1 & \\
\hline Worsened & 08 & 27.6 & 23 & 69.7 & 23 & 71.9 & \\
\hline
\end{tabular}

$p<0.0071 .{ }^{*}$ Kruskal-Wallis Test; †VAS: Visual and analog scale, $\ddagger$ sd=respiratory deviation.

When comparing the groups on Mean Difference (MD) in the VAS scores after treatment, differences in all assessments between the IG and CG groups were significant (30 min: MD 1.15, 95\% confidence interval $(\mathrm{Cl})$ 0.20-2.10, $\mathrm{p}$-value=0.0179; $60 \mathrm{~min}$ : MD 1.45, Cl 0.52-2.39, $\mathrm{p}=0.0023$; 120 min: MD 1.58, Cl 0.61-2.54, p=0.0014 - GEE Test - Generalized estimating equations). Already the MD of the VAS scores between groups IG vs PG (30 min: MD 0.36, Cl -0.73-1.45, $p=0.5143$; 60 min: $M D 0.66, \mathrm{Cl}-0.42-1.74, \mathrm{p}=0.2331 ; 120 \mathrm{~min}: 0.86, \mathrm{Cl}-0.21-1.93, \mathrm{p}=0.1167)$ and $P G$ vs $C G$ (30 min: MD -0.79, Cl 1.18-0.21, p=0.1203; 60 min: MD -0.80, Cl -1.81-0.22, $p=0.1247 ; 120$ min: MD $-0.72, \mathrm{Cl}-1.76-0.32, \mathrm{p}=0.1733$ ) were not statistically significant. MD analyses are not shown in the tables and were performed for the purpose of comparisons between groups (one group to another) during the study periods.

Analyses and comparisons of the parturients' perception of the risk of responding to "the pain worsened" were significant across all assessments when comparing the IG and and the CG after treatment, and between the IG vs the PG with 60 minutes and 120 minutes (Table 4). 
Table 4 - Risk of presenting "the pain worsened" response among the parturients groups. Campinas, São Paulo, 2016

\begin{tabular}{lcccc}
\hline \multirow{2}{*}{ Comparison } & \multirow{2}{*}{ Relative Risk } & \multicolumn{2}{c}{ Confidence interval (95\%) } & \multirow{2}{*}{ p-value } \\
\cline { 3 - 4 } & & Lower limit & Upper limit & \\
\hline Pain, 30 min of treatment & & & & \\
Intervention vs placebo & 2.42 & 0.86 & 6.77 & $0.0931^{*}$ \\
Intervention vs control & 2.95 & 1.08 & 8.02 & $0.0345^{*}$ \\
Placebo vs control & 0.82 & 0.43 & 1.55 & $0.5440^{*}$ \\
Pain, 60 min of treatment & & & & \\
Intervention vs placebo & 3.34 & 1.43 & 7.81 & $0.0054^{*}$ \\
Intervention vs control & 3.26 & 1.39 & 7.66 & $0.0066^{*}$ \\
Placebo vs control & 1.02 & 0.67 & 1.56 & $0.9141^{*}$ \\
Pain, 120 min of treatment & & & & \\
Intervention vs placebo & 2.53 & 1.34 & 4.75 & $0.0040^{*}$ \\
Intervention vs control & 2.61 & 1.39 & 4.88 & $0.0028^{*}$ \\
Placebo vs control & 0.97 & 0.71 & 1.33 & $0.8469^{*}$ \\
\hline
\end{tabular}

VS $=$ Versus $p<0.05$. *GEE Test - Generalized estimating equations.

Regarding intravenous or intramuscular analgesics administered during labor, only one parturient received dipyrone $1,000 \mathrm{mg}$, and another meperidine $50 \mathrm{mg}$ in the CG. Epidural anesthesia or combined block (spinal anesthesia + epidural) were available to parturients, depending on the request; their uses were common in the three groups, occurring in 22 parturients $(64.7 \%)$ in the IG; $29(85.3 \%)$ in the PG; and $21(61.8 \%)$ in the CG ( $p=0.0678$, Chi-square test).

The day after delivery, when asked about the perception of pain improvement after receiving auriculotherapy, $21(61.8 \%)$ IG parturients answered that pain "improved" and only four (11.8\%) did so in the $P G(p=0.0001$, Fisher's exact test $)$.

\section{DISCUSSION}

With regard to the factors considered influential on pain during the parturition process: intensity, duration of contractions, time of fetal presentation and conduction of labor with prostaglandins and/ or oxytocytes, together with the presence or absence of a companion of choice, which may increase the parturient's perception of pain, there was no statistical difference between the groups. Thus, the control variables were homogeneous during the study.

Pain perception and pain intensity were lower in IG parturients. The results of this RCT showed that the reduction in the VAS scores in the studied periods was small in IG; however, this characteristic was not present in the PG and in the CG, with increased VAS scores and a higher risk of "the pain worsened" responses among participants. Considering that pain in the active phase of labor is progressive, the mere fact that it has not increased its intensity demonstrates the efficacy of the care provided. ${ }^{15} \mathrm{~A}$ prior $\mathrm{RCT}{ }^{10}$ of auricular therapy $(n=80)$ on referred pain of parturients in labor and stimulation at similar points: uterus, endocrine, shenmen and spleen, in the results, the mean pain intensity by the VAS after intervention was significantly lower in the auricular therapy group ( 7.56 vs control: $8.43, p<0.05$ ), which shows a useful effect of the therapy on pain during labor and corroborates the findings of this RCT.

Another auricular therapy study, ${ }^{17}$ of a convergent care methodology and qualitative modality, assessed the perception of pain by the VAS responses of 19 women in labor, who had their auricular points stimulated with crystal microspheres: shenmen, central nervous system and kidney, and 
seven other points of systemic acupuncture. After 30 minutes of the intervention, 15 parturients (79\%) reported pain relief, after 2 hours, half of them worsened and the other half maintained the same classification; the results showed the beneficial effect of the auricular therapy in this phase of labor, but the methodology used limits comparisons.

A US RCT, ${ }^{18}$ with 152 women, with 25 to 38 weeks of gestational age and pregnancy-associated lower back and pelvic pain, allocated them into three groups to receive: semipermeable needle auricular therapy (points: shenmen, analgesia and kidney), sham points (placebo) and no intervention (control) for seven days and monitored for 14 days. This study showed a greater reduction in the VAS scores on the seventh day in the auricular therapy group ( $81 \%$ versus placebo $59 \%$ vs control $47 \%, p=0.015)$. The pain of the uterine contractions may radiate to the lower back and be reported by parturients based on the outcomes in these results, ${ }^{16}$ auricular therapy may also be beneficial on low back pain in labor, the objective of this study.

Other studies with parturients used acupuncture or acupressure to relieve pain in labor. In Iran, a study ${ }^{19}$ with acupuncture on BP6 and IG4 points and sham acupuncture (CG) 63 nulliparous women were participants and were evaluated for pain intensity, duration of labor and serum cortisol levels. There were no significant variations in pain (acupuncture: 2.38 vs CG: $2.50, p=0.850$ ) or serum cortisol levels (acupuncture: $26 \mathrm{nmol} / \mathrm{L}$ versus CG: $29 \mathrm{nmol} / \mathrm{L}, \mathrm{p}=0.939$ ). However, the duration of labor was significantly lower in the group receiving true acupuncture (162 minutes VS 280 minutes, $p<0.001)$. Acupressure at the BP6 point reduced the pain scores of parturients in a Brazilian RCT. ${ }^{15}$ In the study, 156 parturients randomly assigned to three groups participated: acupressure, PG and CG; the VAS score differences after treatment were statistically significant (acupressure: - 1.5 vs PG: 0.5 VS CG: 0.6, p<0.0001).

In this RCT, the PG received glass microspheres at sham points; the mean VAS score was lower when compared to the CG. Some authors ${ }^{20}$ described that the placebo effect may occur on acupuncture to some degree, as with any other therapeutic intervention; however, the women with placebo in this study did not receive sham point stimuli at any time. It should also be considered that the various forms of care and continuous support to the parturient can reduce pain complaints during contractions and favor the evolution of labor, as shown in some studies. ${ }^{21-22}$ The day after delivery, the memory of perceived pain improvement after auricular therapy was significantly higher in the IG compared to the PG, but the "halo effect" should be considered ${ }^{23}$ in the immediate post-partum period, when this information was collected in the study.

The use of intravenous or intramuscular analgesic was little requested among the parturients of the study. Epidural analgesia or combined block were common in all three groups. These resources are available to parturients in the obstetric unit, as requested by women and medical evaluation, but there was no statistical difference in their uses.

Acupuncture or auricular therapy analgesia involves the stimulation of small diameter nerves and a differentiated threshold. These nerves send messages to the spinal cord, which activates the brainstem and hypothalamus neurons, triggering endogenous opioid mechanisms. ${ }^{24}$ Such stimuli occur in auricular therapy through acupuncture needles, microspheres or by heating, and are recorded by sensory receptors in the skin of the ear, which drives the central nervous system. In a study ${ }^{25}$ with functional magnetic resonance imaging, stimulation of the thumb ear point revealed an extensive activation of the right, primary and secondary sensory motor cortex (M1, SI and SII), with maximum activity in the pre-central gyrus. The cerebral trunk (another point studied) activated cortical and limbic regions that are part of the pain matrix. The results of this study may show that the respective points are linked to the therapeutic indications in auricular therapy, according to the TCM. Therefore, other points should be further explored in this context of care.

The place of study may be one of the limitations of this RCT, as it is a university hospital, a regional reference for high-risk pregnancy and, therefore, may contribute to high rates of care 
interventions. Another restriction was the lack of data on parturients who used some alternative therapy, available in the routine of the obstetric unit, because these activities are of free adherence and there is a wide variation of frequency and time of use during labor. The parturients of the third group (CG) did not receive the fixation of the microspheres in the ear pinion; blinding was limited to the IG and PG groups for the evaluators; however, for the statistics professional, the three groups. The intervention was performed by the main researcher, because it was difficult for other professionals to apply the therapy in the period and place of study, but the study evaluators who collected the information for the variables and outcomes studied did not participate in the intervention and did not know the allocation group.

\section{CONCLUSION}

The use of auricular therapy showed effectiveness on pain in the evaluated context. In this study, women of the G1 undergoing auricular therapy had reduced VAS scores and a lower risk of pain "worsened" responses up to 120 minutes. In the PG and CG groups, there was an increase in pain scores in all evaluation periods. However, further auricular therapy studies on pain during labor, including larger sample RCTs conducted in environments that promote the physiological evolution of labor, where interventional practices are not routinely used, may result in larger or clearer differences between the study groups.

\section{REFERENCES}

1. Santana LS, Gallo RBS, Ferreira, CHJ Quintana, SM Marcolin. Pain location during early active labor stage. Rev Dor [Internet]. 2013 Sept [cited 2016 Nov 14]; 14(3):184-6. Available from: https://dx.doi.org/10.1590/S1806-00132013000300006

2. Machado PG, Gomes TM, Peripolli RA, Flores PL, Tatsch NE, Diniz ESB. Perception of the nursing team about the pain of the parturient: perspectives for care. Rev Rene [Internet]. $2015 \mathrm{Dec}$ [cited 2018 Sept 25];16(6):881-9. Available from: http://www.redalyc.org/articulo.oa?id=324043261017

3. Almeida NAM, Medeiros M, Souza MR. Sentidos da dor do parto normal na perspectiva e vivência de um grupo de mulheres usuárias do sistema único de saúde. REME Rev Min Enferm [Internet]. 2012 Jun [cited 2016 Nov 14]; 16(2):241-50. Available from: http://www.reme.org.br/ artigo/detalhes/525

4. Schlaeger JM, Gabzdyl EM, Bussell JL, Takakura N, Yajima H, Takayama M, et al. Acupuncture and Acupressure in Labor. J Midwifery Women's Health [Internet]. 2017 Jan [cited 2017 Apr 07]; 62(1):12-28. Available from: https://dx.doi.org/10.1111/jmwh.12595

5. Smith CA, Crowther CA, Grant SJ. Acupuncture for induction of labour. Cochrane Database of Syst Rev [Internet]. 2013 Jan [cited 2016 Nov 06]; 1:D002962. Available from: https://dx.doi. org/10.1002/14651858.CD002962.pub2

6. Levett KM, Smith CA, Dahlen HG, Bensoussan A. Acupuncture and acupressure for pain management in labour and birth: a critical narrative review of current systematic review evidence. Complement Ther Med [Internet]. 2014 Apr [cited 2016 Nov 10]; 22(3):523-40. Available from: https://dx.doi.org/10.1016/j.ctim.2014.03.011

7. Zhao HJ, Tan JY, Wang T, Jin L. Auricular therapy for chronic pain management in adults: a synthesis of evidence. Complement Ther Med [Internet]. 2015 May [cited 2016 Nov 10]; 21(2):6878. Available from: https://dx.doi.org/10.1016/j.ctcp.2015.03.006

8. Reilly PM, Buchanan TM, Vafides C, Breakey S, Dykes P. Auricular acupuncture to relieve health care workers' stress and anxiety: impact on caring. Dimens Crit Care Nurs [Internet]. 2014 Jun [cited 2016 Nov 09]; 33(3):151-9. Available from: https://www.ncbi.nlm.nih.gov/pubmed/24704740 
9. Nogier R. Auriculotherapy. New York(US): Thieme; 2009.

10. Rastegarzade $H$, Abedi $P$, Valiani $M$, Haghighi $M H$. The effect of auriculotherapy on labor pain intensity in nulliparous women (persian). JAP. 2015; 6(1):54-63.

11. Mafetoni RR, Shimo AKK. Effects of auriculotherapy on labour pain: a randomized clinical trial. Rev Esc Enferm USP [Internet]. 2016 Oct [cited 2018 Sept 25];50(5):726-32. Available from: http://www.scielo.br/scielo.php?script=sci_arttext\&pid=S0080-62342016000500726

12. Pereira LV, Sousa FAEF. Postoperative pain measurement and assessment: a brief review. Rev Latino-Am Enfermagem [Internet]. 1998 Jul [cited 2015 Jan 15]; 6(3):77-84. Available from: https://dx.doi.org/10.1590/S0104-11691998000300010

13. Montenegro CAB, Rezende Filho J. Rezende obstetrícia fundamental. 13th ed. Rio de Janeiro(BR): Guanabara Koogan; 2014.

14. Mafetoni RR, Shimo AKK. Effects of acupressure on progress of labor and cesarean section rate: randomized clinical trial. Rev Saúde Pública [Internet]. 2015 Feb [cited 2015 Apr 14]; 49:9. Available from: https://dx.doi.org/10.1590/S0034-8910.2015049005407

15. Mafetoni RR, Shimo AKK. The effects of acupressure on labor pains during child birth: randomized clinical trial. Rev. Latino-Am. Enfermagem [Internet]. 2016 Aug [cited 2016 Dec 10]; 24:e2738. Available from: https://dx.doi.org/10.1590/1518-8345.0739.2738

16. Boutron I, Altman DG, Moher D, Schulz KF, Ravaud P. CONSORT Statement for randomized trials of nonpharmacologic treatments: a 2017 update and a CONSORT extension for nonpharmacologic trial abstracts. Annals of Internal Medicine [Internet]. 2017 Jul [cited 2019 Aug 14];167(1):40-7. Available from: http://www.consort-statement.org/extensions?ContentWidgetld $=558$

17. Cherobin F, Oliveira AR, Brisola AM. Acupuncture and auriculotherapy as non-pharmacological pain relief methods in the childbirth process [Internet]. 2016 Sept [cited 2018 Sept 25]; 21(3):0107. Available from: https://revistas.ufpr.br/cogitare/article/view/45152/pdf_en

18. Wang SM, Dezinno P, Lin EC, Lin H, Yue JJ, Berman MR, et al. Auricular acupuncture as a treatment for pregnant women who have low back and posterior pelvic pain: a pilot study. Am J Obst Gynecol [Internet]. 2009 Sept [cited 2017 Jun 18]; 201(3):271.e1-9. Available from: https:// dx.doi.org/10.1016/j.ajog.2009.04.028

19. Asadi N, Maharlouei N, Khalili A, Darabi Y, Davoodi S, Raeisi SH, et al. Effects of LI-4 and SP-6 acupuncture on labor pain, cortisol level and duration of labor. J Acupunct Meridian Stud [Internet]. 2015 Oct [cited 2017 Sept 14]; 8(5):249-54. Available from: https://dx.doi.org/10.1016/j. jams.2015.08.003

20. Medeiros R, Saad M. Acupuntura: efeitos fisiológicos além do efeito placebo. Mundo saúde [Internet]. 2009 Mar [cited 2017 Sept 16]; 33(1):69-72. Available from: https://www.saocamilo-sp. br/pdf/mundo_saude/66/69a72.pdf

21. Diniz CSG, D'Orsi E, Domingues RMSM, Torres JÁ, Dias MAB, Schneck CA, et al. Implementation of the presence of companions during hospital admission for childbirth: data from the birth in Brazil national survey. Cad Saúde Pública [Internet]. 2014 [cited 2014 Oct 12]; 30(suppl 1):s140-s153. Available from: https://dx.doi.org/10.1590/0102-311X00127013

22. Pereira ALF, Nagipe SFS, Lima GPV, Nascimento SD, Gouveia MSF. Care and outcomes of relaxation room assistance at a public maternity hospital, Rio de Janeiro, Brazil. Texto contexto enferm. [Internet]. 2012 Sept [cited 2018 Jan 20]; 21(3):566-73. Available from: http://www.scielo. br/scielo.php?script=sci_arttext\&pid=S0104-07072012000300011\&lng=pt

23. Azevedo AC, D'Andretta TAC. Collective memories of women who have experienced maternal near miss: health needs and human rights. Cad. Saúde Pública [Internet]. 2016 [cited 2018 Sept 25]; 32(9):e00161215. Available from: http://www.scielo.br/scielo.php?script=sci_arttext\&pid=S0102311X2016000905011\&lng=en 
24. Kurebayashi LFS, Silva MJP. Chinese auriculotherapy to improve quality of life of nursing team. Rev Bras Enferm [Internet]. 2015 Feb [cited 2017 Sept 14]; 68(1):117-23. Available from: https:// dx.doi.org/10.1590/0034-7167.2015680116p

25. Romoli M, Allais G, Airola G, Benedetto C, Mana O, Giocobbe M. Ear acupuncture and fMRI: a pilot study for assessing the specificity of auricular points. Neurol Sci [Internet]. 2014 May [cited 2017 Nov 12]; 35(1):189-93. Available from: https://dx.doi.org/10.1007/s10072-014-1768-7 


\section{NOTES}

\section{ORIGIN OF THE ARTICLE}

Article extracted from dissertation -Effects of auricular therapy on labor: a randomized clinical trial, presented to the Graduate Nursing Program of the Nursing School of the Universidade Estadual de Campinas, in 2017.

\section{CONTRIBUTION OF AUTHORSHIP}

Study desing: Mafetoni RR, Shimo AKK.

Data collection: Mafetoni RR.

Analysis and interpretation of data: Mafetoni RR, Rodrigues MH, Silva FMB, Shimo AKK. Discussion of the results: Mafetoni RR, Rodrigues MH, Silva FMB, Jacob LMS, Shimo AKK.

Writing and/or critical review of content: Mafetoni RR, Rodrigues MH, Silva FMB, Jacob LMS, Shimo AKK.

Review and final approval of the final version: Mafetoni RR, Rodrigues MH, Silva FMB, Jacob LMS, Shimo AKK.

\section{ACKNOWLEDGMENT}

To Henrique Ceretta Oliveira, from the Nursing School of the Universidade Estadual de Campinas, for his contribution to the statistical analysis.

\section{ETHICS COMMITTEE IN RESEARCH}

Approved by the Ethics Committee in Research with Human Beings of the Schoo of Medical Sciences of the Universidade Estadual de Campinas, Opinion No. 855.496/Certificate of Presentation for Ethical Appreciation No. 35671514.6.0000.5404.

Registration: No. RBR-47hhbj.

\section{CONFLICT OF INTERESTS}

There is no conflict of interest.

\section{HISTORICAL}

Received: April 3, 2018.

Approved: October 29, 2018.

\section{CORRESPONDENCE AUTHOR:}

Reginaldo Roque Mafetoni

mafetoni.cps@gmail.com 